NBER WORKING PAPER SERIES

\title{
CAPITAL MOBILITY AND ECONOMIC PERFORMANCE: ARE EMERGING ECONOMIES DIFFERENT?
}

\author{
Sebastian Edwards \\ Working Paper 8076 \\ http://www.nber.org/papers/w8076 \\ NATIONAL BUREAU OF ECONOMIC RESEARCH \\ 1050 Massachusetts Avenue \\ Cambridge, MA 02138 \\ January 2001
}

This is a revised version of a paper presented at the annual Kiel Institute Conference. Kiel, Germany, June, 2000. I am indebted to Denis Quinn and to Gian Maria Milesi-Ferreti for making their data available, and to Ignacio Magendzo and Alejandrín Jara for helpful research Assistance. I thank Ricardo Hausmann for his comments. I have benefitted from discussions with Ed Leamer. The views expressed herein are those of the author and not necessarily those of the National Bureau of Economic Research.

(C) 2001 by Sebastian Edwards. All rights reserved. Short sections of text, not to exceed two paragraphs, may be quoted without explicit permission provided that full credit, including $\odot$ notice, is given to the source. 
Capital Mobility and Economic Performance: Are Emerging Economies Different?

Sebastian Edwards

NBER Working Paper No. 8076

January 2001

JEL No. F1, F3, O4

\begin{abstract}
In this paper I use a new cross-country data set to investigate the effects of capital mobility on economic growth. The new indicator of capital mobility used in this analysis is superior to previously used indexes in two respects: (1) It allows for intermediate situations, where a country's capital account is semi-open; and (2) it is available for two different periods in time. The results obtained suggest that, after controlling for other variables (including aggregate investment), countries with a more open capital account have outperformed countries that have restricted capital mobility. There is also evidence, however, suggesting that an open capital account positively affects growth only after a country has achieved a certain degree of economic development. This provides support to the view that there is an optimal sequencing for capital account liberalization.
\end{abstract}

Sebastian Edwards

UCLA Anderson Graduate School of Business

110 Westwood Plaza, Suite C508

Box 951481

Los Angeles, CA 90095-1481

and NBER

sebastian.edwards@anderson.ucla.edu 


\section{Introduction}

Political opposition to "globalization" has grown rapidly during the last few years. Protesters in Seattle, Washington D.C. and other cities around the world have rallied against the alleged evils of an increasingly interconnected world economy, and of the socalled "Washington Consensus."

The opening of domestic capital markets to foreigners is, perhaps, the most reviled aspect of this "consensus." In rejecting a higher degree of capital mobility across countries, the anti-globalization activists and protesters are not alone. Indeed, a number of academics have argued that the free(er) mobility of private capital during the 1990s was behind the succession of crises that the emerging markets experienced during that decade. According to this view, increased capital mobility inflicts many costs and generates (very) limited benefits to the emerging nations. It has been argued that, since emerging markets lack modern financial institutions, they are particularly vulnerable to the volatility of global financial markets. This vulnerability, the story goes, will be higher in countries with a more open capital account. Moreover, many global-skeptics have argued that there is no evidence supporting the view that a higher degree of capital mobility has a positive impact on economic growth in the emerging economies (Rodrik 1998).

Surprisingly, the debate on the effects of capital mobility on economic performance has been characterized by a very limited number of empirical analyses. Some exceptions are Rodrik (1998), Klein and Olivei (1999), Quinn (1997) and Reisen and Soto (2000). The purpose of this paper is to analyze empirically the relationship between economic performance and capital mobility in the world economy. I am particularly interested in understanding two related issues: First, is there any evidence, at the cross country level, that higher capital mobility is associated (after controlling for other factors) with higher growth? And, second, is the relationship between capital mobility and growth different for emerging and advanced countries? The paper is organized as follows: Section I is the introduction. In section II I provide an analysis of the magnitude, importance, composition and other characteristics of capital flows in the world economy between 1975and 1997. In section III I deal with measurement problems. I argue that the 
complications associate to the measurement the actual, as opposed to legal, degree of capital mobility makes the analysis of the connection between capital mobility and growth particularly difficult. In this section I discuss the properties of various measures on the degree of capital mobility recently constructed by a number of analysts. In section IV I report the results from a series of cross-country regressions on economic performance. I focus on two independent variables - GDP growth, and total factor productivity growth - and I control for the standard variables, including human capital and the initial degree of economic development. Finally, section IV is the conclusions.

\section{Capital Flows in the World Economy During 1975-1997}

In this section I focus on the behavior of capital flows in the world economy during the last two decades. The main objective of this analysis is to unearth regularities, and to detect differences across groups of countries. I consider six groups of countries, that correspond to the IMF's International Financial Statistics classification: (1) Industrial, (2) African, (3) Asian, (4) Non-industrial European, (5) Middle East and (6) Western Hemisphere or Latin America and the Caribbean. In addition, I make a distinction between three type of capital flows: (1) Foreign direct investment (FDI); (2) debt flows, including debt to banks and bonds purchased by foreigners; and (3) other type of flows, mostly portfolio equity flows.

In Tables 1 through 5 I summarize the behavior of capital flows to these six regions during the period under study. I provide data on averages, medians, standard deviations and coefficients of variation for the volumes of flows relative to GDP. ${ }^{\square}$ While Table 1 contains data for the complete period, Tables 2 through 4 present data for each category of capital flows - debt, FDI, equities and total flows - for three different subperiods: The first period is $1975-82$, and corresponds to the years prior to the debt crisis of 1982. The second subperiod is 1983-89, and corresponds to the years when most emerging countries had difficulties attracting foreign capital. The final subperiod is 1990-97, a period when private capital flew, once again, into the emerging economies. This period also corresponds to the initiation of market-oriented reforms in most regions in the world, including the former communist nations.

\footnotetext{
1 These data have been constructed as differences in stocks. The raw data comes from the World Bank.
} 
Visual inspection of Tables 1 through 5 suggests that capital flows have behaved differently across categories, regions and periods. Flows appear to have been more volatile in the emerging economies and in particular in Africa. These tables also capture the slowdown in flows in the period 1983-89, when most of the emerging world was battling the consequences of the debt crisis, and the resumption of capital flows in the 1990s, including the surge of portfolio flows. It is also apparent from these figures that Africa has been lagging behind other emerging nations in most capital flows categories.

In order to test formally whether capital flows behaved differently across countries, I estimated a series of non parametric Kruskal-Wallis $\chi^{2}$ tests on the equality of the distribution of capital flows in each of the five emerging market regions and the industrial countries. The null hypothesis is that the data from the industrial nations and from each of the emerging regions have been drawn from the same population. The Kruskal-Wallis $\chi^{2}$ test is computed as:

$$
K=\left\{[12 / n(n+1)] \sum\left(R_{j}^{2} / n_{j}\right)\right\}-3(n+1),
$$

where $n_{j}$ is the sample size for the $j$ group $(j=1, \ldots m), n$ is the sum of the $n_{j} s, R_{j}$ is the sum of the ranks $\mathrm{j}$ group, and the $\operatorname{sum} \sum \operatorname{runs}$ from $\mathrm{j}=1$ to $\mathrm{j}=\mathrm{m}$.

The results are reported in Table 6. As may be seen, these tests clearly indicate that capital flows have behaved differently in emerging markets (as a group), and in the industrial countries. With the exception of FDI in the $1975-82$ period, the $\chi^{2}$ test statistic is larger than the critical value, for every type of flow and for every subperiod considered in this study. The more detailed analysis by region reveals that in most subperiods and for most regions the hypothesis of equality of distribution is rejected strongly. In the case of Africa the $\chi^{2}$ test statistics are particularly large, and are highly significant in 15 out of sixteen cases. During the more recent $1990-97$ period the $\chi^{2}$ test statistic is below the critical value for FDI flows to Asia, Europe and Western Hemisphere; it is also below its critical value for equity flows into Europe. In spite of these few instances of $\chi^{2}$ test statistics below the critical value, the overall picture that emerges from Table 6 indicates, quite strongly, that when it comes to capital flows (relative to GDP) to the emerging 
markets - both as a broad group and as regional aggregates -- have indeed been different than capital flows to the industrial nations.

\section{Measuring the Extent of Capital Mobility in Emerging and Advanced Economies}

During most of the last 50 years the vast majority of what we today call emerging nations severely controlled international capital movements. This was done through a variety of means, including taxes, administrative restrictions and outright prohibitions. It has only been in the last decade or so that serious consideration has been given to the opening of the capital account in less advanced nations. Many analysts have associated the proposals to free capital mobility with the policy dictates of the so-called “Washington Consensus.” Williamson's (1994) original article on the Washington Consensus, however, says very little about the opening of the capital account. What it does say, however, is that the reform policies favored by the multilaterals included encouraging foreign direct investment and the liberalization of domestic capital markets.

Legally speaking -- and as the IMF documented year after year --, during most of the post World War II era the vast majority of the emerging countries had a closed capital account. From an economic point of view, however, what matters is not the legal degree of capital restrictions, but the actual or "true" degree of capital mobility. There is ample historical evidence suggesting that there have been significant discrepancies between the legal and the actual degree of capital controls. In countries with severe impediments to capital mobility -- including countries that have banned capital movement --, it does not take a long time for the private sector to find ways to get around the restrictions. The most common mechanisms have been the overinvoicing of imports and underinvoicing of exports. The massive volumes of capital flight that took place in Latin America in the wake of the 1982 debt crisis clearly showed that, when faced with the "appropriate" incentives, the public can be extremely creative in finding ways to move capital internationally.

\section{1 Previous Measurement Attempts}

Measuring the "true" degree of capital mobility is not easy, and is still subject to considerable debate. In two early studies Harberger $(1978,1980)$ argued that the effective degree of integration of capital markets should be measured by the convergence of private rates of return to capital across countries. He used national accounts data for a number of 
countries -- including eleven Latin American countries -- to estimate rates of return to private capital, and found out that these were significantly similar. More importantly, he found that these private rates of return were independent of national capital-labor ratios. Harberger interpreted these findings as supporting the view that capital markets are significantly more integrated than what a simple analysis of legal restrictions would suggest.

In an effort to measure the "true" degree of capital mobility, Feldstein and Horioka (1980) analyzed the behavior of savings and investments in a number of countries. They argue that if there is perfect capital mobility, changes in savings and investments will be uncorrelated in a specific country. Using a data set for 16 OECD countries they found that savings and investment ratios were highly positively correlated, and concluded that these results strongly supported the presumption that long term capital was subject to significant impediments. Frankel (1989) applied the Feldstein-Horioka test to a large number of countries during the 1980s, including a number of Latin American nations. His results corroborated those obtained by the original study, indicating that savings and investment have been significantly positively correlated in most countries. Montiel (1994) estimated a series of Feldstein-Harioka equations for emerging countries. He argues that the estimated regression coefficient for the industrial countries could be used as a benchmark for evaluating whether a particular country's capital account is open or not. After analyzing a number of studies he concludes that a saving ratio regression coefficient of 0.6 provides an adequate benchmark: if a country regression coefficient exceeds 0.6 , it can be classified as having a "closed" capital account; if the coefficient is lower than 0.6 the country has a rather high degree of capital mobility. Using this procedure he concludes that many emerging nations have exhibited a remarkable degree of capital mobility - that is, much larger than what an analysis of legal restrictions would suggest.

In a series of studies Edwards $(1985,1988)$ and Edwards and Khan (1985) argued that time series on domestic and international interest rates could be used to assess the degree of openness of the capital account (see also Montiel 1994). The application of this model to the cases of a number of countries (Brazil, Colombia, Chile) confirmed the results that, in general, the actual degree of capital mobility is greater than what the legal restrictions approach suggests. Haque and Montiel (1991), Reisen and Yeches (1991) and Dooley (1995) have provided expansions of this model that allow for the estimation of the 
degree of capital mobility even in cases when there are not enough data on domestic interest rates, and when there are changes in the degree of capital mobility through time. Their results once again indicate that in most Latin American countries "true" capital mobility has historically exceeded "legal" extent of capital mobility. Dooley et al (1997) have developed a model that recognizes the costs of undertaking disguised capital inflows. The model is estimated using a Kalman filter technique for three countries, including Mexico. The results suggest that Mexico, the Philippines and Korea experienced a very significant increase in the degree of capital mobility between 1977 and 1989.

More recently, some authors have used information contained in the International Monetary Fund's Exchange Rate and Monetary Arrangements to construct indexes on capital controls for panels of countries. Alesina, Grilli and Milesi-Ferreti (1994), for example, constructed a dummy variable index of capital controls. This indicator -- which takes a value of one when according to the IMF capital controls are in place and zero otherwise -- was then used to analyze some of the political forces behind the imposition of capital restrictions in a score of countries. Rodrik (1998) used a similar index to investigate the effects of capital controls on growth, inflation and investment between 1979 and 1989 . His results suggest that, after controlling for other variables, capital restrictions have no significant effects on macroeconomic performance. Klein and Olivei (1999) used the IMF's Exchange Rate and Monetary Arrangements data to construct an index of capital mobility. The index is defined as the number of years in the period 1986 and 1995 that, according to the IMF, the country in question has had an open capital account. ${ }^{2}$ In contrast to Rodrik, their analysis suggests that countries with a more open capital account have performed better than those that restrict capital mobility.

An important limitation of these IMF-based indexes, however, is that they are extremely general and do not distinguish between different intensities of capital restrictions. Moreover, they fail to distinguish between the type of flow that is being restricted, and they ignore the fact that, as discussed above, legal restrictions are frequently circumvented. For example, according to this IMF-based indicator, Chile, Mexico and Brazil were subject to the same degree of capital controls in 1992-1994. In reality, however, the three cases were

\footnotetext{
2 Milner (1996), Leblang (1996) and Razin and Rose (1994) have also used indicators based on the IMF binary classification of openness.
} 
extremely different. While in Chile there were restrictions on short-term inflows, Mexico had (for all practical purposes) free capital mobility, and Brazil had in place an arcane array of restrictions. Montiel and Reinhart (1999) have combined IMF and country-specific information to construct an index on the intensity of capital controls in 15 countries during 1990-96. Although their index, which can take three values (0, 1 or 2), represents an improvement over straight IMF indicators, it is still very general, and does not capture the subtleties of actual capital restrictions.

Quinn (1997) has constructed the most comprehensive set of cross country indicators on the degree of capital mobility. His indicators cover 20 advanced countries and 45 emerging economies. These indexes have two distinct advantages over other indicators: First, they are not restricted to a binary classification, where countries capital account's are either open or closed. Quinn uses a 0 through 4 scale to classify the countries in his sample, with a higher number meaning a more open capital account. Second, Quinn indexes cover more than one time period, allowing researchers to investigate whether there is a connection between capital account liberalization and economic performance. This is, indeed, a significant improvement over traditional indexes that have concentrated on a particular period in time, without allowing researchers to analyze whether countries that open up to international capital movements have experienced changes in performance.

\section{III.2 A Comparison of Two Alternative Measures of the Extent of Capital Mobility}

In this sub-section I analyze of the main properties of two broad measures of capital mobility ${ }^{2}$. (1) An index based on the number of years within a certain period that, according to the IMF, a particular country has not imposed capital controls. This is the type of indicator used by Alesina, Grilli and Milesi-Ferreti (1994), and by Rodrik (1998) in his study on the relationship between capital controls and economic performance. I call this index NUYCO. A higher value denotes a higher degree of capital controls. And (2) Quinn's (1997) index of capital mobility. This indicator can take values goes from 0 through 4 , with increments of 0.5. A higher value of this index denotes a higher degree of capital mobility.

\footnotetext{
${ }^{3}$ I am grateful to Gian Maria Milesi-Ferreti for making his data set available to me.
} 
The Number-of-years-with-controls (NUYCO) Index: I computed this index for three periods 1981-85, 1986-1990 and 1981-90 for a sample of 61 countries. Of these 40 are emerging nations and 21 are advanced countries. Panel A in Table 7 contains summary statistics. Two properties of this index emerge from this table. First, as expected, capital controls have been more pervasive among the emerging countries. Second, while the emerging nations appear to have relaxed capital control somewhat during the second half of the 1980s, the emerging countries appear to have tightened them slightly. In order to analyze formally whether this index is statistically different in industrial and emerging countries I computed, once again, Kruskal-Wallis test statistics. The $\chi^{2}$ was ( $\mathrm{p}$ value in parenthesis): 2.33 (0.12) for 1981-85; 5.57 (0.018) for 19851990; and 3.67 (0.057) for the 1981-1990 period. Overall these test statistics confirm the hypothesis that the extent of capital controls has been significantly larger in the emerging countries, especially in the second half of the 1990s.

One of the most serious limitations of the NUYCO index is that it tends to classify most countries in the extremes, as either being subject to no controls, or as completely impeding capital mobility. For the period 1981-85 only eight out of 61 countries have values different from 0 or 5; and for 1985-1990 only three countries have an index value different from the extremes of 0 or 5 . As pointed out above, this inability to consider intermediate cases of limited controls is one of the greatest shortcomings of this index. In my view this problem is so severe that it reduces very significantly its usefulness in empirical cross section analyses.

Quinn's Indicator (CAPOPEN): Panel B in Table 7 contains summary statistics for Quinn's index of capital account restrictions. As was pointed out, this index can take values that go from 0 to 4 , and is available for 65 countries -20 of which are industrial and 45 emerging - and for two periods: the mid 1970s and the mid/late 1980s. ${ }^{\text {G }}$ As may be seen from Table 7, according to this indicator the advanced countries have had a more open capital account than the emerging economies. These data also suggest that the difference between the two groups of countries became more accentuated in the late

\footnotetext{
${ }^{4}$ This could be, in part, a result of these countries efforts to get over the debt crisis of 1982. Formally testing this proposition, however, is beyond the scope of this paper.

${ }^{5}$ The index used by Klein and Olivei (1999) also suffers from this limitation. The very vast majority of countries in their sample appear to be either completely open or completely closed to capital mobility.
} 
1980s. The Kruskal-Wallis $\chi^{2}$ for equality of the distribution across the two groups of countries is ( $\mathrm{p}$ value in parenthesis): 5.1 (0.02) for the mid 1970s; and 23.7 (0.0001) for the 1980s. In contrast with the NUYCO index, Quinn's indicator allows for considerable gradation in the extent of capital mobility. For instance, for the 1970s in 49 of the 65 countries the index has a value other than the extremes of 0 or 4 . In the 1980s there are 46 countries with an intermediate value for the index - that is a value that is neither 0 (the capital account is completely closed) or 4 (the capital account is completely open). For example, while according to NUYCO Greece and Ireland had a completely closed capital account during the second half of the 1980s, according to Quinn's index they had a semiopen capital account during this period.

An important feature of Quinn's index is that it has been computed for two different periods, allowing us to investigate the effects of capital account liberalization on economic performance. In order to understand further the properties of Quinn's indexes, I compared them with an indicator based on Montiel's (1994) savings-investments regressions for emerging countries. The Spearman rank correlation coefficient had the expected sign, but was rather low. Moreover the null hypothesis of both indexes being independent could not be rejected at conventional values.

\section{Capital Mobility and Economic Performance: New Results}

In principle, a greater of openness of the capital account can impact on economic performance through two alternative channels. The first, and most obvious one, is through it effect foreign savings, and through them, on aggregate investment. Countries with a more open capital account will have, in principle, the ability to finance a larger current account deficit, and thus increase the volume of foreign savings. If increases in foreign services are not reflected in a one-to-one decline in domestic savings, aggregate savings will be higher. This will allow for higher investment and, thus, faster growth.

Figure 1 presents the relationship between the degree of capital account liberalization during the 1980s - denoted as (qopen87-qopen73), and measured in the horizontal axis --, and the change in aggregate capital inflows, measured in the vertical axis. This figure suggests, quite strongly, that countries that reduced the degree of capital controls experienced an increase in capital inflows. This, in turn, was translated into

\footnotetext{
${ }^{6}$ The indexes were formally computed for 1973 and 1987. See Quinn (1997) for details.
} 
higher current account deficits. Whether this, in turn, resulted in higher aggregate investment depends on the extent to which foreign savings crowd out domestic savings and is, ultimately, an empirical issue.

In Edwards (1996) I used a broad cross-country data set to analyze this issue. My results suggested that an increase in the current account deficit - that is, an increase in foreign savings - crowd out private domestic savings partially. The point estimate ranged (in absolute value) from 0.38 to 0.625 , depending on the specification used for the regression. These results were confirmed by the direct estimation of investment equations that included the CAPOPEN index of capital mobility as a regressor. These regressions are similar to those estimated by Barro and Sala-I-Martin (1995), and are not reported here due to space considerations.

The second (potential) channel through which capital mobility may affect performance refers to efficiency and productivity growth. According to a number of authors, the elimination of capital controls, reduces an important distortion, and will tend to result in higher return to investment, and higher productivity growth. That is, according to this channel, countries with a more open capital account will outperform those with restrictions on capital mobility, even after controlling for the direct investment effect. In this section I use the data described above to investigate the importance of this particular channel.

\section{IV.2 Basic Econometric Results}

According to economic theory, countries with fewer distortions will tend to perform better than countries with regulations and distortions that impede the functioning of markets. For some time now, most (but not all) economists have agreed that freer trade in goods and services indeed result in faster growth (Barro, 1995; Edwards 1998). In standard models this 'free trade' principle extends to the case of trade in securities, and countries that have fewer restrictions on capital mobility will, with other things given, tend to outperform countries that isolate themselves from global financial markets. This view is clearly exposed by Rogoff (1999, p.23):

"From a theoretical perspective, there are strong analogies between gains in intertemporal trade in goods, and standard intratemporal trade...In theory, huge long-

\footnotetext{
${ }^{7}$ Results are available from the author on request.
} 
run efficiency gains can be reaped by allowing global investment to flow towards countries with low capital-labor ratios...[R]esearchers have now come to believe that the marginal gains [international] trade in equities can be very large... [It allows countries] to diversify production risk, which allows smaller countries to specialize, and more generally to shift production towards higher-risk, higher return projects"

Whether gains from an open capital account are as large as Rogoff believes, is largely an empirical question. In this section I use a new cross-country data set to investigate this issue. More specifically, I concentrate on two measures of performance: real GDP growth, and total factor productivity growth during the 1980s. I rely on Quinn's index to measure the degree of capital mobility in different countries. The data on GDP growth are taken from Summers and Heston and those on TFP growth are from Edwards (1998).

From a policy perspective analysts are interested in two related issues: (a) Have countries with a more open capital account performed better - in terms of higher productivity growth and per capita GDP growth -- than countries that restrict capital mobility? (b) Have countries that have opened their capital account performed differently than countries that have not done so? As noted, a particular important question is whether there is a "performance effect" over and above the investment effect discussed above. One of the advantages of Quinn's index is that is available at two different periods in time, allowing us to address both of these questions. The analysis presented in this section investigates the relationship between capital account restrictions and economic performance, is based on the estimation of the following two equations:

$$
\begin{aligned}
& g_{j}=\alpha_{0}+\alpha_{1} \kappa_{j}+\Sigma \alpha_{2} \mathbf{X}_{\mathbf{j}}+\varepsilon_{j} \\
& \tau_{j}=\beta_{0}+\beta_{1} \boldsymbol{\kappa}_{\mathbf{j}}+\Sigma \beta_{2} \mathbf{X}_{\mathbf{j}}+\mu_{\mathrm{j}},
\end{aligned}
$$

where $g_{j}$ is average real GDP growth in country $\mathrm{j}$ during the $1980 \mathrm{~s} ; \tau_{\mathrm{j}}$ is the average rate of TFP growth during the $1980 \mathrm{~s} ; \boldsymbol{\kappa}_{\mathbf{j}}$ is a measure of capital account openness in country j, or an indicator of the extent of capital account liberalization between 1973 and 1987; the $\mathbf{X}_{\mathbf{j}}$ are other variables that affect economic performance; $\varepsilon_{\mathrm{j}}$ and $\mu_{\mathrm{j}}$ are 
heteroskedastic errors with zero mean. The $\alpha$ s and $\beta$ s are parameters to be estimated. Following the recent literature on growth and cross country economic performance in the estimation of equation (3) the following $\mathbf{X}_{\mathbf{j}}$ were included: (a) The investment ratio during the 1980s (INV80). Its coefficient is expected to be positive. (b) A measure of human capital, taken to be the number of years of schooling completed by 1965 (Human). Its coefficient is expected to be positive. And (c) the log of real GDP per capita in 1965, which is take to be a measure of initial economic activity. To the extent that countries real income tends to converge, the coefficient of this variable (GDP651) is expected to be nagative. In the estimation of equation (3) initial GDP and human capital were used as the two $\mathbf{X}_{\mathbf{j}}$.

The first measure of capital account openness (CAPOP) captures the degree of openness of the capital account in each country during the mid/late 1980s and corresponds to Quinn's index discussed above. The second index captures the extent to which capital account restrictions changed between the mid 1970s and the mid/late 1980s . This index, which is denoted D_CAPOP corresponds to Quinn's capital account liberalization indicator; a higher value means that the country in question liberalized its capital account during the period under study. The sign and statistical significance of the capital account openness coefficient, is at the heart of recent discussions on the effects of globalization, and is the main interest of the econometric analysis reported in this section.

Equations (2) and (3) were estimated using a number of procedures, including weighted least squares, weighted two stages least squares, SURE, and weighted three stage least squares. In all regressions GDP per capita in 1985 was used as a weight.

Table 8 summarizes the basic results obtained from the estimation of equations (2) and (3) using the level of capital account restrictions (CAPOP) as the independent variable. In Table 9, on the other hand, I present the regression results from the estimation of these two equations using the capital account liberalization index, D_CAPOP, as the independent variable. ${ }^{\mathrm{B}}$ In both tables the sample includes all countries for which data are available.

\footnotetext{
8 The basic SURE and three stage least square results are not reported due to space considerations. See, however, the discussion below.
} 
As may be seen, the estimated coefficients of human65, inv80, $g d p 65 l$ have the expected signs in every regression. Moreover, in the vast majority of the regressions the estimated coefficients for these variables were significant at conventional levels. More important for the subject matter of this paper is that the coefficients of the capital account openness variables are positive in every regression, and significant in all but one of them. These results suggest that, once controlling for other variables, countries that are more integrated to global financial markets have performed better than countries that have isolated themselves. This is the case both for countries that had a more open capital account and countries that liberalized their capital account.

It is interesting to note that if instead of using Quinn's indexes of capital account restrictions, the more common IMF-based indicator is used, the coefficients become insignificant. For instance, in the WLS estimation of the growth equation, the coefficient of NUYCO is 0.0002 with a t-statistic of 0.657 . When this equation was estimated using IV-WLS the coefficient was 0.0008 and the t-statistic 1.12.

\section{IV.2 Outliers and Measurement Errors}

In order to investigate the robustness of these results, I performed a sensitivity analysis: I checked for the possible undue influence of outliers, and I dealt with measurement error.

Outliers: In order to investigate the possible undue influence of outlier observations, I computed Cook's Influence distance test. The results point out towards three potential outliers: Nicaragua, India and Ethiopia. When these countries were excluded from the estimation, however, the results did not changed in any relevant way: countries with a amore open capital account and countries that have liberalized capital flows appear to have outperformed more isolationist nations.

Errors in Variables: Even though Quinn's indicators of capital account restrictions are vastly superior that the more traditional ones - including the IMF-based indexes used by Rodrik (1998) and others --, they are still an imperfect measure of the "true" degree of capital mobility. In that sense, the estimation of equations (2) and (3) are subject to a classical error-in-variables problem. The traditional, textbook solution to this problem is to estimate the equation en question using instrumental variables. If the "mis-measured" variable is properly instrumented, the estimated coefficient is consistent. 
In that sense, then, it is possible to argue that since the results reported above were obtained with instrumental variables, the measurement problem has been properly tackled.

In the current case, however, the extent of measurement error is likely to be more severe than the simple textbook case. Indeed in this case all independent variables are (possibly) measured with error. Klepper and Leamer (1984) have shown that when measurement error is generalized, it is possible to use a set of reversed regressions to compute bounds for the coefficients of interest. These authors show that if there are no changes in the pattern of coefficient signs when estimating the reversed regressions, the "true" value of each coefficient will be bounded by the minimum and maximum estimates from the set of reversed and direct regressions. If, on the other hand, there is a change in the sign pattern of any of the coefficients, it is necessary to bring in additional information to be able to bound the coefficients.

Following Klepper and Leamer (1984) I estimated the reversed regressions corresponding to equations (2) and (3), and analyzed the sign pattern of the coefficients. Unfortunately, in each equation there were two sign changes, indicating that it is not straightforward to bound the "true" coefficients. This suggests that the estimates reported above are (somewhat) fragile. In order to address this issue further, I estimated the critical minimal level for the $\mathrm{R}^{2}$ between the dependent and the "true" (error free) explanatory variable, that is consistent with a coefficients vector bounded by the original orthant. For the TFP equation on capital account liberalization, this minimum value, or

$\mathrm{R}_{\mathrm{m}}{ }^{2}$, is 0.57 . This critical value is not completely unreasonable, indicating that, although the estimated equations (2) and (3) are fragile - in the sense that the reversed regression coefficients exhibit a sign switch --, it is possible to assume that their "true" values correspond to those obtained in the direct regressions. In that sense, then, this analysis provides some further support for the finding that, at least for the period under consideration counties with a greater degree of integration with the rest of the world performed better than more isolated nations.

\section{IV.3 How Different are Emerging Countries?}

As pointed out in section I of this paper, one of the most important policy questions - and one that is at the heart of recent debates on globalization - is whether the 
effects of globalization on economic performance is similar in advanced and in emerging economies. In fact, according to many intellectually prominent global skeptics, capital account liberalization is not bad per se,. The problem, in their view, is that the emerging countries are unprepared for it. The problem is, according to this view, that the poor nations do not have the required institutions to handle efficiently large movements of capital. In this subsection I provide some preliminary results that address this issue. Due to space considerations I concentrate on the case when the degree of capital account openness is used as the independent variable. More specifically, I investigate whether the effect of capital restrictions on growth depends on the country's level of development. I do this by adding the interactive independent variable (log GDPC * CAPOP) in the estimation of equations (2) and (3). GDPC is GDP per capita in 1980. In this case, equation (2) becomes:

$$
\begin{aligned}
\mathrm{g}_{\mathrm{j}}=\alpha_{0} & +\alpha_{1} \text { CAPOP }_{\mathrm{j}}+\alpha_{2}\left(\text { CAPOP }_{\mathrm{j}} \log \text { GDPC }_{\mathrm{j}}\right)+\alpha_{3} \text { human65 }_{\mathrm{j}}+ \\
& +\alpha_{14} \log \text { GDPC65 }_{\mathrm{j}}+\varepsilon_{\mathrm{j}} .
\end{aligned}
$$

If coefficient $\alpha_{2}$ is significant, the the total effect of capital openness on growth becomes country-specific, and will be given by:

$$
\mathrm{E}_{\mathrm{j}}=\alpha_{1}+\alpha_{2} \log \mathrm{GDPC}_{\mathrm{j}}
$$

If $\alpha_{2}$ is positive (negative), the effect of capital account openness on growth increases (declines) with the level of development. Table 10 contains the results obtained from the three stages least squares estimation of equations (2) and (3), with an added interactive regressor. As may be seen, all the coefficients are significant at conventional levels. More important, however, the coefficient of the interactive term $\left(\right.$ CAPOP $_{j} \log$ GDPC $\left._{j}\right)$ is positive, indicating that the effect of a more open capital account increases with the initial level of development of the county. Furthermore, since the coefficient of the openness index is negative, an open capital account may in fact have a negative effect at very low levels of development. 
A particularly important question is what is the average value of the total effect coefficients $\left(\alpha_{1}+\alpha_{2} \log\right.$ GDPC $\left._{j}\right)$ for industrial and emerging countries. In both equations these averages were positive for the advanced nations and negative for the emerging countries. The actual averages in the growth equation were (standard errors in parentheses), 0.0075932 (0.0035522) for industrial countries and -0.0104921 (0 .0091007) for emerging nations. In the TFP growth equation the industrial average was 0.0133434 (0.0083494), while the emerging markets average was -0.0133434 (0.0083494). Notice, however, that not every emerging country has a negative $\left(\alpha_{1}+\alpha_{2}\right.$ $\log \mathrm{GDPC}_{\mathrm{j}}$ ) coefficient. In fact, in the case of the growth equation, the following emerging countries had a positive "total effect" coefficient:

Israel

Venezuela

Hongkong

Singapore

Mexico.

\section{Conclusions}

Although this analysis is preliminary, the results reported in this paper suggests, quite strongly, that the positive relationship between capital account openness and productivity performance only manifests itself after the country in question has reached a certain degree of development. A plausible interpretation is that countries can only take advantage, in the net, of a greater mobility of capital once they have developed a somewhat advanced domestic financial market. I explored this interpretation by a term that interacted the CAPOP index with standard measures of domestic financial development, including the ratio of liquid liabilities in the banking sector to GDP and the exchange rate black market premium. Broadly speaking, these results support the view that while for financially sophisticated countries an open capital account is a boon, at very low levels of local financial development a more open capital account may have a negative effect on performance. In that sense, then, emerging markets are essentially "different" from advanced nations. 


\section{BIBLIOGRAPHY}

Alesina, Alberto; Vittorio Grilli and Gian-Maria Milesi, 1994. “"The Political Economy of Capital Controls"; in L. Leiderman and A. Razin, (eds.), Capital Mobility: The Impact on Consumption, Investment and Growth.. Cambridge, New York and Melbourne: Cambridge University Press, pages 289-321.

Barro, Robert and Xavier Sala-I-Martin, 1995. Economic Growth, Mc Graw Hill. Bhagwati, Jagdish. 1998. The Capital Myth: The Difference Between Trade in Widgets and Trade in Dollars" Foreign Affairs, 77, 7-12

Bosworth, Barry, Rudi Dornbusch and Raúl Labán. 1994. The Chilean economy: Lessons and Challenges, The Brookings Institution.

Budenich, Carlos and Guillermo Lefort. 1997. "Capital Account Regulation and Macroeconomics Policy: Two Latin American Experiences", Banco Central de Chile

Calvo, Guillermo 1998. "The Simple Economics of Sudden Stops”, Journal of Applied Economics, 1, 1

Campbell, John, Andrew Lo and A. Craig MacKinlay. 1997. The Econometrics of Financial Markets, Princeton University Press.

Cooper, Richard N. 1998. "Should Capital Account Convertibility be a World Objective?” Essays in International Finance No. 207

Cowan, Kevin and José De Gregorio. 1997. "Exchange Rate Policies and Capital Account Management: Chile in the 1990s" Departamento de Ingeniería Industrial, Universidad de Chile.

Cuddington, John. 1986. Capital Flight: Estimates, issues and Explanations. Princeton Essays in International Finance, No. 58.

De Gregorio, José, Sebastian Edwards and Rodrigo Valdés. 1998. "Capital Controls in Chile: An Assessment" Presented at the Interamerican Seminar on Economics, Rio de Janeiro, Brazil. http://www.anderson.ucla.edu/faculty/sebastian.edwards/

Dooley, Michael, D. Mathieson, and L. Rojas-Suarez 1997. “Capital Mobility, and Exchange Market Intervention in Developing Countries, “ NBER Working Paper, 6247. 
Dornbush, Rudiger. 1998. "Capital Controls: An Idea Whose Time is Past" Essays in International Finance No. 207

Dornbush, Rudiger and Sebastian Edwards. 1991. The Macroeconomics of Populism in Latin America. University of Chicago Press.

Edwards, Sebastian 1989. Real Exchange Rates, Devaluation and Adjustment, The MIT Press.

Edwards, Sebastian 1998a. "Capital Flows, Real Exchange Rates and Capital Controls: Some Latin American Experiences" NBER Working Paper 6000. Also in author's web page: http://www.anderson.ucla.edu/faculty/sebastian.edwards/

Edwards, Sebastian 1998b. "Interest Rate Volatility, Contagion and Convergence: An Empirical Investigation of the Cases of Argentina, Chile and Mexico.” Journal of Applied Economics, 1,1.

Edwards, Sebastian 1998c:"Openness, Productivity and Growth: What do we

Really Know?" The Economic Journal, also in: http://www.anderson.ucla.edu/faculty/sebastian.edwards/

Edwards, Sebastian and Alejandra Cox Edwards, 1991. Monetarism and Liberalization: The Chilean Experiment. University of Chicago Press.

Edwards, Sebastian and Julio Santaella, 1993. Devaluation Controversies in the Developing Countries. In Michael Bordo and Barry Eichengreen (Eds) A Retrospective on the Bretton Woods System. University of Chicago Press.

Eichengreen, Barry. 1999. Toward a New International Financial Architecture: A Practical Post-Asia Agenda, Institute for International Economics.

Eichengreen, Barry and Charles Wyplosz. 1993. “The Unstable EMS”, Brookings Papers on Economics Activity. 51-143.

Feldstein, Martin and Charles Horioka, 1980. "Domestic Saving and International Capital Flows", Economic Journal 90 (June): 314-29.

Fischer, Stanley. 1998. "Capital Account Liberalization and the Role of the IMF>" Princeton Essays on International Finance, 207.

Garber, Peter M. 1998. "Buttressing Capital Account Liberalization with Prudential Regulation and Foreign Entry.” Essays in International Finance No. 207 Goldman-Sachs. 1997. Emerging Markets Biweekly. Several Issues. 
Hanson, James. 1995. "Opening the Capital Account: Costs, Benefits and Sequencing" in Edwards, Sebastian ed.. Capital Controls, Exchange Rates and Monetary Policy in the World Economy. Cambridge: Cambridge University Press

Ito, Taka and Richard Portes. 1998. "Dealing with the Asian Financial Crises", European Economic Perspectives, CERP.

Kaminsky, Graciela L. and Carmen M. Reinhart. 1999. "The Twin Crises: The Causes of Banking and Balance of Payments Problems." American Economic Review, 89, 473-500

Klein M. and G. Olivei (1999), “Capital Account Liberalization, Financial Depth and Economic Growth” NBER Working Paper 7384.

Krugman, Paul. 1998. "Saving Asia: It's Time to get Radical”, Fortune, September 7 p. $74-80$.

Krugman, Paul. 1999. “Depression Economics Returns”, Foreign Affairs, 78, 1

Labán, Raúl and Felipe Larraín. 1997. "El Retorno del los Capitales privados a Chile en los Noventa: Causas, Efectos y Reacciones de Política" Cuadernos de Economía, 103

Massad, Carlos, 1998a. "The Liberalization of the Capital Acount: Chile in the 1990s”, Essays in International Finance N0. 207

Massad, Carlos, 1998b. "La Política Monetaria en Chile," Economía Chilena, 1, 1

McKinnon, Ronald I. 1973. Money and Capital in economic Development. The Brookings Institution.

McKinnon, Ronald I. 1991. The Order of Economic Liberalization. Johns Hopkins University Press.

McKinnon, Ronald I. and Howard Pill. 1995. "Credit Liberalization and International Capital Flows." Department of Economics, Stanford University

Mishkin, Frederic. 1999. “Global Financial Instability” Journal of Economic Perspectives (this issue)

Montiel, Peter. 1994. "Capital mobility in Developing Countries: Some Measurement Issues and Empirical Estimates" World Bank Economic Review, 8, 3 
Montiel, Peter and Carmen Reinhart. 1999. "Do Capital Controls and Macroeconomics Policies Influence the Volume and Composition of Capital Flows? Evidence from the 1990s. University of Maryland.

Obstfeld, Maurice and Kenneth Rogoff. 1996. Foundations of International Finance, The MIT Press.

Quinn, Dennis, 1997. “Correlates of Changes in International Financial regulation", American Political Science review, 91, 3:531-551

Reisen, H. and M. Soto (2000), "The Need for Foreign Savings in Post-Crisis Asia”, OECD.

Rodrik, Dani, 1998. “Who Needs Capital-Account Convertibility?”, in Should the IMF Pursue Capital-Account Convertibility, Essay in International Finance No 207. Princeton University.

Rogoff, Keneth. 1999. "International Institutions for Reducing Global Financial Instability" Journal of Economic Perspectives (1999)

Soto, Claudio. 1997. "Controles a los Movimientos de Capitales: Evaluación Empírica del Caso Chileno" Banco Central de Chile

Stiglitz, Joseph, 1999 "Bleak Growth Prospects for the Developing World”, International Herald Tribune, April 10-11, 1999, p. 6.

Tobin, James. “A Prposal for International Monetary Reform," Eastern Economic Journal, p. 154-159.

Valdés-Prieto, Salvador and Marcelo Soto 1996. "Es el Control Selectivo de Capitales Efectivo en Chile? Su efecto Sobre el Tipo de Cambio Real" Cuadernos de Economía, 98

Valdés-Prieto, Salvador and Marcelo Soto 1998. "The Effectiveness of Capital Controls: Theory and Evidence from Chile" Empirica 25, 2.

World Bank. 1993. Latin America a Decade After the Debt Crisis. Washington, D.C.

Zahler, Roberto M. 1992. "Plítica Monetaria en un Contexto de Apertura de la Cuenta de Capitales". Speech delivered at the $54^{\text {th }}$ Meeting of Latin American Central Bank Governors, San Salvador, El Salvador, May 5, 1992. 
FIGURE 1: Capital Account Liberalization and Capital Inflows as Percentage of GDP: 1980s

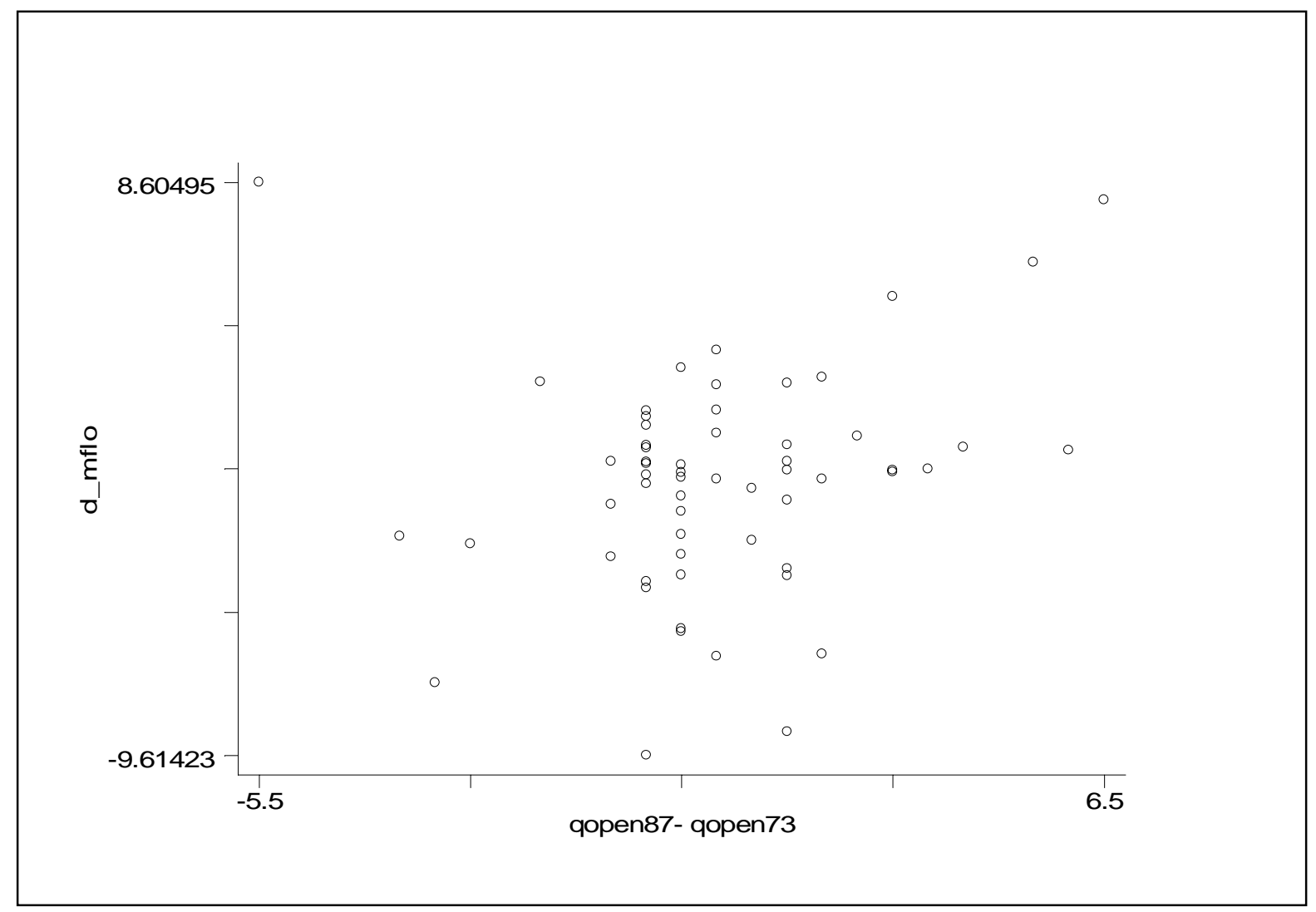




\section{TABLE 1}

Capital Flows as Percentage of GDP:

Regional Data, 1975-97

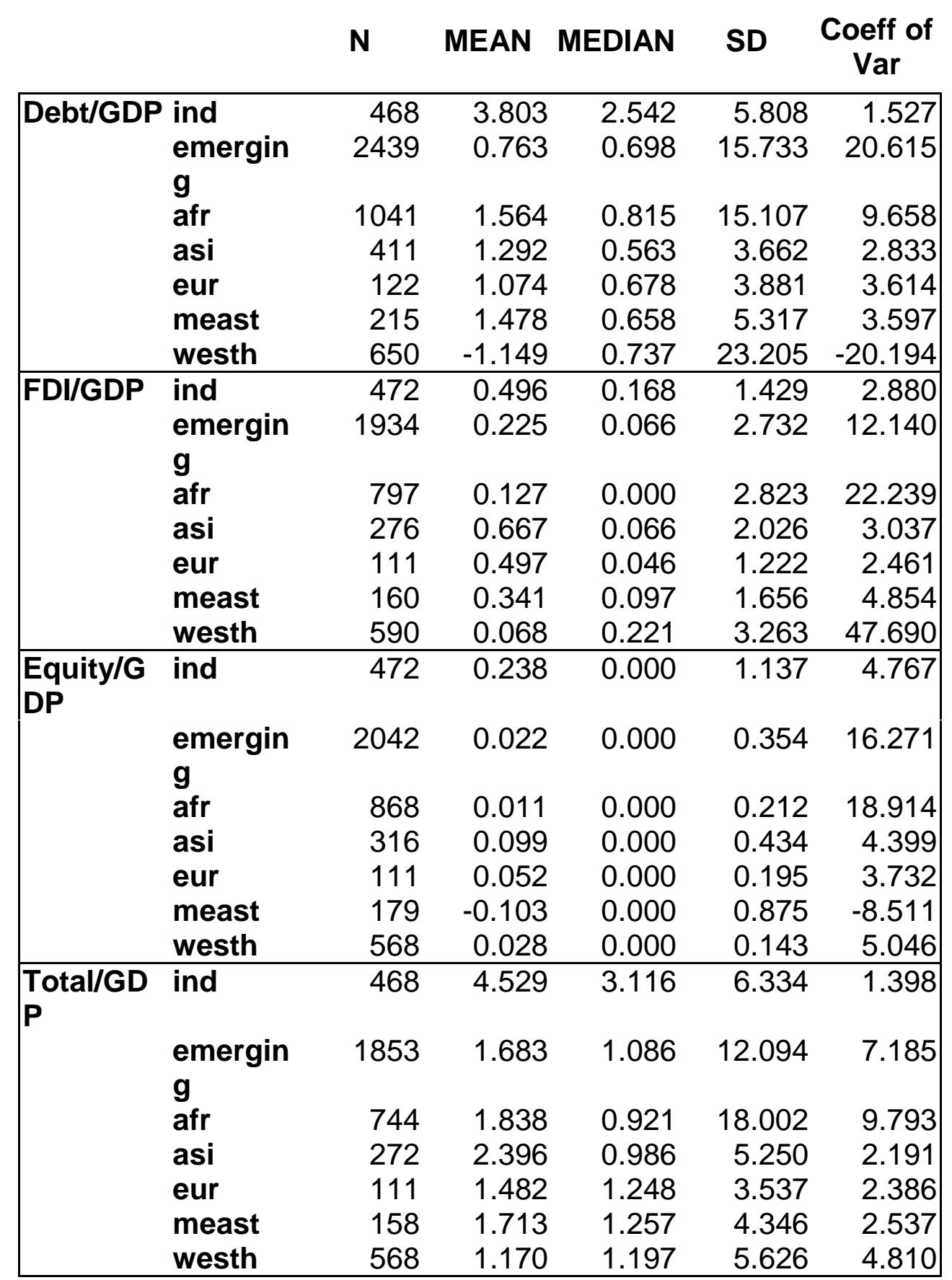

Source: World Bank 
TABLE 2

Debt Capital Flows as Percentage of GDP:

Regional Data: Alternative Periods, 1975-97

\begin{tabular}{|c|c|c|c|c|c|c|}
\hline \multirow{2}{*}{$\begin{array}{l}1975- \\
1982\end{array}$} & & \multirow{2}{*}{$\frac{N}{158}$} & MEAN & MEDIAN & \multirow{2}{*}{$\frac{S D}{4.550}$} & \multirow{2}{*}{$\begin{array}{r}\text { COEF VAR } \\
1.367\end{array}$} \\
\hline & ind & & 3.328 & 2.165 & & \\
\hline & emergin & 827 & 1.116 & 1.477 & 21.504 & 19.273 \\
\hline & $\begin{array}{l}\mathrm{g} \\
\text { afr }\end{array}$ & 357 & 2.725 & 1.698 & 25.114 & 9.215 \\
\hline & asi & 127 & 1.707 & 0.700 & 2.962 & 1.735 \\
\hline & eur & 37 & 2.260 & 1.001 & 5.895 & 2.608 \\
\hline & meast & 80 & 2.341 & 1.593 & 4.074 & 1.740 \\
\hline & wes & 226 & -2.380 & 82 & 25.808 & -10.844 \\
\hline \multirow{7}{*}{\begin{tabular}{|l|}
$1983-$ \\
1989
\end{tabular}} & ind & 146 & 3.926 & 2.891 & 3.944 & 1.005 \\
\hline & emergin & 764 & 1.019 & 0.743 & 10.281 & 10.088 \\
\hline & $\begin{array}{l}\mathrm{g} \\
\text { afr }\end{array}$ & 324 & 1.990 & 1347 & 5.131 & \\
\hline & asi & 132 & 1.020 & 0.6 & 2.820 & 2.764 \\
\hline & eur & 36 & 0.338 & 0.323 & 2.545 & 7.531 \\
\hline & meast & 68 & 1.402 & 0.732 & 3.075 & 2.193 \\
\hline & west & 204 & -0.531 & 0.556 & 18.492 & -34.811 \\
\hline \multirow{7}{*}{$\begin{array}{l}1990- \\
1997\end{array}$} & ind & 164 & 4.151 & 2.508 & 7.907 & 1.905 \\
\hline & emergin & 848 & 0.189 & 0.196 & 12.877 & 68.222 \\
\hline & $\begin{array}{l}\mathrm{g} \\
\text { afr }\end{array}$ & 360 & 0.029 & 0.134 & 2.860 & 97.275 \\
\hline & asi & 152 & 1.182 & 0.422 & 4.687 & 3.96 \\
\hline & eur & 49 & 0.719 & 1.101 & 2.358 & 3.280 \\
\hline & meast & 67 & 0.525 & -0.101 & 7.771 & 14.797 \\
\hline & westh & 220 & -0.458 & 0.114 & 24.333 & 53 \\
\hline
\end{tabular}

Source: World Bank 
TABLE 3

FDI Capital Flows as Percentage of GDP:

Regional Data: Alternative Periods, 1975-97

\begin{tabular}{|c|c|c|c|c|c|c|}
\hline \multirow{2}{*}{$\begin{array}{l}1975- \\
1982\end{array}$} & & \multirow{2}{*}{$\frac{N}{160}$} & MEAN & MEDIAN & \multirow{2}{*}{$\frac{S D}{1.063}$} & \multirow{2}{*}{$\begin{array}{r}\text { COEF VAR } \\
10.763\end{array}$} \\
\hline & ind & & 0.099 & 0.026 & & \\
\hline & emergin & 669 & 0.146 & 0.011 & 2.374 & 16.207 \\
\hline & $\begin{array}{l}\mathrm{g} \\
\text { afr }\end{array}$ & 288 & 0.131 & 0.000 & 2.916 & 22.185 \\
\hline & asi & 87 & 0.492 & 0.002 & 1.605 & 3.260 \\
\hline & eur & 32 & 0.053 & 0.000 & 0.937 & 17.756 \\
\hline & meast & 59 & 0.701 & 0.157 & 1.766 & 2.519 \\
\hline & wes & 203 & -0.127 & 0.083 & 2.053 & -16.183 \\
\hline \multirow{7}{*}{\begin{tabular}{|l|}
$1983-$ \\
1989
\end{tabular}} & ind & 147 & 0.496 & 0.136 & 1.389 & 2.800 \\
\hline & emergin & 621 & -0.062 & 0.000 & 3.183 & -51.691 \\
\hline & $\begin{array}{l}g \\
\text { afr }\end{array}$ & 259 & -0.054 & -0.1 & 2.093 & 38. \\
\hline & asi & 90 & 0.456 & 0.003 & 1.974 & 4.330 \\
\hline & eur & 35 & 0.206 & 0.000 & 0.769 & 3.739 \\
\hline & meast & 49 & 0.422 & 0.058 & 1.533 & 3.632 \\
\hline & westh & 188 & -0.496 & 0.000 & 4.959 & -10.007 \\
\hline \multirow{7}{*}{$\begin{array}{l}1990- \\
1997\end{array}$} & ind & 165 & 0.882 & 0.545 & 1.658 & 1.881 \\
\hline & emergin & 644 & 0.583 & 0.221 & 2.569 & 4.406 \\
\hline & $\begin{array}{l}\mathrm{g} \\
\text { afr }\end{array}$ & 250 & 0.309 & 0.017 & 3.327 & 10.759 \\
\hline & asi & 99 & 1.012 & 0.252 & 2.350 & 2.323 \\
\hline & eur & 44 & 1.051 & 0.582 & 1.480 & 1.408 \\
\hline & meast & 52 & -0.144 & 0.086 & 1.546 & -10.740 \\
\hline & westh & 199 & 0.800 & 0.582 & 1.808 & 2.25 \\
\hline
\end{tabular}

Source: World Bank 
TABLE 4

Portfolio Capital Flows as Percentage of GDP:

Regional Data: Alternative Periods, 1975-97

\begin{tabular}{|c|c|c|c|c|c|c|}
\hline & & $\mathrm{N}$ & MEAN & MEDIAN & $\mathrm{SD}$ & COEF VAR \\
\hline \multirow{7}{*}{$\begin{array}{l}1975- \\
1982\end{array}$} & ind & 160 & -0.059 & 0.000 & 0.380 & -6.426 \\
\hline & emergin & 717 & 0.022 & 0.000 & 0.369 & 16.794 \\
\hline & $\begin{array}{l}g \\
\text { afr }\end{array}$ & 314 & 0.007 & 0.000 & 0.206 & 27.60 \\
\hline & asi & 101 & 0.057 & 0.000 & 0.230 & 4.046 \\
\hline & eur & 32 & 0.000 & 0.000 & 0.000 & \\
\hline & meast & 67 & 0.115 & 0.000 & 1.086 & 9.461 \\
\hline & westh & 203 & 0.000 & 0.000 & 0.021 & -128.270 \\
\hline \multirow{7}{*}{$\begin{array}{l}1983- \\
1989\end{array}$} & ind & 147 & 0.318 & 0.000 & 1.571 & 4.947 \\
\hline & emergin & 680 & -0.021 & 0.000 & 0.295 & -14.163 \\
\hline & $\begin{array}{l}g \\
\text { afr }\end{array}$ & 301 & -0.005 & 0.000 & 0.095 & -18.461 \\
\hline & asi & 104 & 0.048 & 0.000 & 0.303 & $\begin{array}{r}-10.40 \\
6.337\end{array}$ \\
\hline & eur & 35 & 0.000 & 0.000 & 0.001 & 5.916 \\
\hline & meast & 56 & -0.320 & 0.000 & 0.866 & $\begin{array}{r}-2.703 \\
\end{array}$ \\
\hline & westh & 184 & 0.002 & 0.000 & 0.014 & 7.810 \\
\hline \multirow{7}{*}{$\begin{array}{l}1990- \\
1997\end{array}$} & ind & 165 & 0.457 & 0.175 & 1.111 & 2.432 \\
\hline & emergin & 645 & 0.066 & 0.000 & 0.386 & 5.822 \\
\hline & $\begin{array}{l}g \\
\text { afr }\end{array}$ & 253 & & & & 8.528 \\
\hline & asi & 111 & 0.184 & 0.000 & 0.627 & 3.40 \\
\hline & eur & 44 & 0.131 & 0.049 & 0.294 & 2.236 \\
\hline & meast & 56 & -0.145 & 0.000 & 0.450 & -3.097 \\
\hline & westh & 181 & 0.087 & 0.000 & 0.241 & 2.772 \\
\hline
\end{tabular}

Source: World Bank 
TABLE 5

Total Capital Flows as Percentage of GDP:

Regional Data: Alternative Periods, 1975-97

\begin{tabular}{|c|c|c|c|c|c|l|}
\hline & & $\mathbf{N}$ & $\begin{array}{c}\text { MEA } \\
\text { MEDIA }\end{array}$ & SD & COEF \\
\hline $\mathbf{1 9 7 5 -}$ & ind & 158 & 3.352 & 2.385 & 4.871 & 1.453 \\
& & & & & & \\
& emergin & 661 & 2.573 & 1.876 & 18.97 & 7.374 \\
g & & & & 0 & \\
afr & 280 & 2.976 & 1.640 & 28.67 & 9.637 \\
& & & & & 7 & \\
& asi & 87 & 2.601 & 1.258 & 4.274 & 1.643 \\
& eur & 32 & 2.023 & 1.233 & 4.864 & 2.404 \\
& meast & 59 & 3.129 & 2.702 & 4.278 & 1.367 \\
& westh & 203 & 1.930 & 1.976 & 4.751 & 2.462 \\
$\mathbf{1 9 8 3 -}$ & ind & 146 & 4.756 & 3.463 & 5.171 & 1.087 \\
& & & & & & \\
& emergin & 610 & 1.470 & 0.726 & 5.451 & 3.709 \\
& g & & & & & \\
& afr & 252 & 1.843 & 0.903 & 5.553 & 3.013 \\
& asi & 90 & 1.616 & 0.727 & 4.112 & 2.544 \\
& eur & 35 & 0.520 & 0.274 & 2.791 & 5.371 \\
& meast & 49 & 1.990 & 1.109 & 3.820 & 1.920 \\
& westh & 184 & 0.929 & 0.436 & 6.508 & 7.004 \\
ind & 164 & 5.461 & 3.957 & 8.126 & 1.488 \\
$\mathbf{1 9 9 9}$ & & & & & & \\
& emergin & 582 & 0.897 & 0.645 & 4.967 & 5.540 \\
& g & & & & & \\
& afr & 212 & 0.330 & 0.351 & 3.624 & 10.969 \\
& asi & 95 & 2.947 & 1.033 & 6.768 & 2.297 \\
& eur & 44 & 1.855 & 1.700 & 2.772 & 1.495 \\
& meast & 50 & -0.229 & -0.417 & 4.268 & -18.635 \\
westh & 181 & 0.562 & 0.667 & 5.499 & 9.789 \\
\hline
\end{tabular}

Source: World Bank 
Table 6

Kruskal-Wallis Test for Equality of Samples

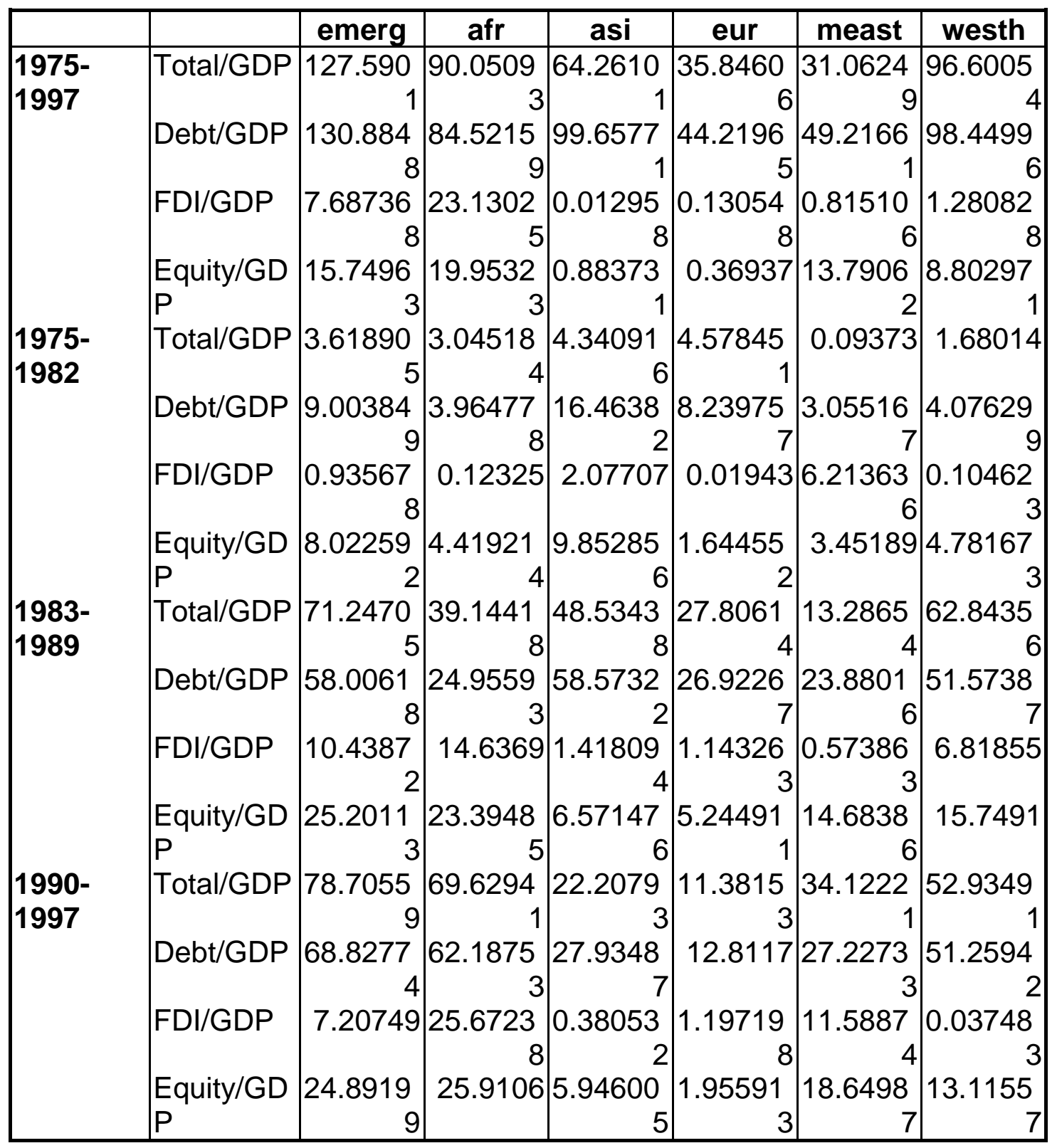

- The null hypothesis is that each emerging region comes from the same population than the industrial countries. The test is distributed $\chi^{2}$ with one degree of freedom. The critical value at the $10 \%$ level is 2.71 . 
Table 7

Alternative Indicators of Capital Mobility:

Summary Statistics

\section{A. NUYCO INDEX}

\section{A.1 All Countries}

\begin{tabular}{|l|l|l|l|l|l|}
\hline & Obs & Mean & Std. Dev. & Min & Max \\
\hline & & & & & \\
\hline $\begin{array}{l}\text { NUYCO8 } \\
5\end{array}$ & 61 & 3.737705 & 2.040438 & 0 & 5 \\
\hline $\begin{array}{l}\text { NUYCO9 } \\
0\end{array}$ & 61 & 3.737705 & 2.136209 & 0 & 5 \\
\hline $\begin{array}{l}\text { NUYCO8 } \\
19\end{array}$ & 61 & 7.47541 & 4.002527 & 0 & 10 \\
\hline
\end{tabular}

\section{A.2 Industrial Countries}

\begin{tabular}{|l|l|l|l|l|l|}
\hline Variable & Obs & Mean & Std. Dev. & Min & Max \\
\hline $\begin{array}{l}\text { NUYCO8 } \\
5\end{array}$ & 21 & 3.142857 & 2.329929 & 0 & 5 \\
\hline $\begin{array}{l}\text { NUYCO9 } \\
0\end{array}$ & 21 & 2.714286 & 2.452404 & 0 & 5 \\
\hline $\begin{array}{l}\text { NUYCO8 } \\
19\end{array}$ & 21 & 5.857143 & 4.607447 & 0 & 10 \\
\hline
\end{tabular}

\section{A. 3 Emerging Countries}

\begin{tabular}{|l|l|l|l|l|l|}
\hline Variable & Obs & Mean & Std. Dev. & Min & Max \\
\hline $\begin{array}{l}\text { NUYCO8 } \\
5\end{array}$ & 40 & 4.05 & 1.82504 & 0 & 5 \\
\hline $\begin{array}{l}\text { NUYCO9 } \\
0\end{array}$ & 40 & 4.275 & 1.753933 & 0 & 5 \\
\hline $\begin{array}{l}\text { NUYCO8 } \\
19\end{array}$ & 40 & 8.325 & 3.407289 & 0 & 10 \\
\hline
\end{tabular}




\section{B. QUINN INDEX (CAPOP)}

\section{B.1 All Countries}

\begin{tabular}{|l|l|l|l|l|l|}
\hline Variable & Obs & Mean & Std. Dev. & Min & Max \\
\hline & & & & & \\
\hline CAPOP73 & 65 & 2.069231 & 1.089283 & 0 & 4 \\
\hline CAPOP87 & 65 & 2.338462 & 1.142597 & 0 & 4 \\
\hline
\end{tabular}

\section{B.2 Industrial Countries}

\begin{tabular}{|l|l|l|l|l|l|}
\hline Variable & Obs & Mean & Std. Dev. & Min & Max \\
\hline & & & & & \\
\hline CAPOP73 & 21 & 2.452381 & .756716 & 1.5 & 4 \\
\hline $\begin{array}{l}\text { CAPOP } \\
87\end{array}$ & 21 & 3.333333 & .5773503 & 2.5 & 4 \\
\hline
\end{tabular}

\section{B.3 Emerging Markets}

\begin{tabular}{|l|l|l|l|l|l|}
\hline Variable & Obs & Mean & Std. Dev. & Min & Max \\
\hline $\begin{array}{l}\text { CAPOP } \\
73\end{array}$ & 44 & 1.886364 & 1.180577 & 0 & 4 \\
\hline $\begin{array}{l}\text { CAPOP } \\
87\end{array}$ & 44 & 1.863636 & 1.036338 & 0 & 4 \\
\hline
\end{tabular}

Source: See text 


\section{Table 8}

\section{Capital Account Openness and GDP Growth: Cross Country Econometric Results, 1980s (Weighted Least Squares and Instrumental Variables WLS)*}

\section{A. Real GDP Growth, Weighted Least Squares: All Countries}

\begin{tabular}{|l|l|l|l|l|}
\hline gro80s & Coef. & Std. Err. & t & P>t \\
\hline & & & & \\
\hline Capop87 & .0030046 & .0023936 & 1.255 & 0.215 \\
\hline human65 & .0031461 & .001128 & 2.789 & 0.007 \\
\hline gdp651 & -.0123794 & .0041281 & -2.999 & 0.004 \\
\hline inv80s & .1603782 & .0283357 & 5.660 & 0.000 \\
\hline _cons & .0539573 & .0283515 & 1.903 & 0.062 \\
\hline
\end{tabular}

Number of obs $=59 ; \quad F(4,54)=13.14 ;$ R-squared $=0.4932$

\section{B. Real GDP Growth, IV-Weighted Least Squares: All Countries*}

\begin{tabular}{|l|l|l|l|l|}
\hline gro80s & Coef. & Std. Err. & $\mathrm{t}$ & $\mathrm{P}>\mathrm{t}$ \\
\hline & & & & \\
\hline Capop87 & .0079586 & .0035431 & 2.246 & 0.029 \\
\hline human65 & .0029805 & .001113 & 2.678 & 0.010 \\
\hline gdp651 & -.0162367 & .0044724 & -3.630 & 0.001 \\
\hline inv80s & .1475412 & .0287109 & 5.139 & 0.000 \\
\hline _cons & .0765549 & .0298211 & 2.567 & 0.013 \\
\hline
\end{tabular}

Number of obs $=56 ; \quad F(4,51)=13.70 ; \quad$ R-squared $=0.5023$

\section{C: TFP Growth, Weighted Least Squares: All Countries}

\begin{tabular}{|l|l|l|l|l|}
\hline tfp80 & Coef. & Std. Err. & $\mathrm{t}$ & $\mathrm{P}>\mathrm{t}$ \\
\hline & & & & \\
\hline Capop87 & .0053182 & .00277 & 1.920 & 0.060 \\
\hline human65 & .0048019 & .0012986 & 3.698 & 0.000 \\
\hline gdp651 & -.0124138 & .0047 & -2.641 & 0.011 \\
\hline _cons & .0612132 & .0329048 & 1.860 & 0.068 \\
\hline
\end{tabular}

Number of obs $=62 ; \quad F(3,58)=8.31 ; \quad$ R-squared $=0.3006$

\section{D: TFP Growth, IV-Weighted Least Squares: All Countries**}

\begin{tabular}{|l|l|l|l|l|}
\hline tfp80 & Coef. & Std. Err. & t & P>t \\
\hline & & & & \\
\hline Capop87 & .0059084 & .002569 & 2.300 & 0.025 \\
\hline human65 & .0019274 & .0008243 & 2.338 & 0.023 \\
\hline gdp651 & -.0058782 & .0033151 & -1.773 & 0.082 \\
\hline cons & .0223116 & .0217966 & 1.024 & 0.311 \\
\hline
\end{tabular}

Number of obs $=58: \quad F(3,54)=6.84 ; \quad$ R-squared $=0.1758$

* Instruments: human6 gdp65 qcap7 $11 y 70$ inv80 open80 dist 1 ly75 bmp751

** Instruments: human6 gdp65 qcap7 1 ly70 open80 dist 1 ly75 bmp751 


\section{Table 9}

Capital Account Liberalization and GDP Growth:

Cross Country Econometric Results, 1980s

(Weighted Least Squares and Instrumental Variables WLS)*

\section{A. Growth, Weighted Least Squares: All Countries}

\begin{tabular}{|l|l|l|l|l|}
\hline gro80s & Coef. & Std. Err. & $\mathrm{t}$ & $\mathrm{P}>\mathrm{t}$ \\
\hline & & & & \\
\hline human65 & .0028349 & .0011286 & 2.512 & 0.015 \\
\hline gdp651 & -.0101456 & .0038152 & -2.659 & 0.010 \\
\hline inv80s & .1550862 & .0281895 & 5.502 & 0.000 \\
\hline D_capop & .003052 & .0015201 & 2.008 & 0.050 \\
\hline _cons & .0443192 & .0272326 & 1.627 & 0.110 \\
\hline
\end{tabular}

$\mathrm{F}(4,53)=14.17 ;$ Prob $>\mathrm{F}=0.0000 ;$ R-squared $=0.5167 ; \mathrm{N}=59$

\section{B. Growth, IV-Weighted Least Squares: All Countries*}

\begin{tabular}{|l|l|l|l|l|}
\hline gro80s & Coef. & Std. Err. & $\mathrm{t}$ & $\mathrm{P}>\mathrm{t}$ \\
\hline & & & & \\
\hline D_capop & .0051239 & .0026291 & 1.949 & 0.057 \\
\hline gdp651 & -.0096943 & .0039819 & -2.435 & 0.019 \\
\hline inv80s & .1515098 & .030562 & 4.957 & 0.000 \\
\hline human65 & .0024621 & .0012104 & 2.034 & 0.047 \\
\hline _cons & .0416354 & .0285659 & 1.458 & 0.151 \\
\hline
\end{tabular}

$\mathrm{F}(4, \quad 50)=12.49 ;$ Prob $>\mathrm{F}=0.0000 ; \quad \mathrm{R}$-squared $=0.4883 ; \mathrm{N}=55$

C. TFP Growth, IV, Weighted Least Squares: All Countries**

\begin{tabular}{|l|l|l|l|l|}
\hline tfp80 & Coef. & Std. Err. & $\mathrm{t}$ & $\mathrm{P}>\mathrm{t}$ \\
\hline & & & & \\
\hline qdcap738 & .0053401 & .0016531 & 3.230 & 0.002 \\
\hline human65 & .00144 & .0008524 & 1.689 & 0.097 \\
\hline gdp651 & -.0019287 & .0027714 & -0.696 & 0.490 \\
\hline cons & .0042915 & .0200442 & 0.214 & 0.831 \\
\hline
\end{tabular}

Number of obs $=57 ; \quad F(3, \quad 53)=8.49 ; \quad$ R-squared $=0.1884$

\section{TFP Growth, Weighted Least Squares: All Countries}

\begin{tabular}{|l|l|l|l|l|}
\hline tfp80 & Coef. & Std. Err. & t & P>t \\
\hline & & & & \\
\hline qdcap738 & .0025068 & .0009653 & 2.597 & 0.012 \\
\hline human65 & .001953 & .000744 & 2.625 & 0.011 \\
\hline gdp651 & -.0017833 & .0024749 & -0.721 & 0.474 \\
\hline cons & .0024587 & .0178655 & 0.138 & 0.891 \\
\hline
\end{tabular}

Number of obs $=60 ; \quad F(3,56)=9.24 ; \quad$ R-squared $=0.3311$

* The following instruments were used: (human65 gdp651 inv80 qcap58 qopen58 qopen73 qcap73 lly75 dist)

** Instruments: human6 gdp65 qcap7 lly70 open80 dist lly75 bmp751) 


\section{Table 10}

Capital Account Openness and Growth:

The Role of Interactive Terms

(Weighted Three Stages Least Squares)

Equation
grosos

